\title{
Rural Telecom Services: Marketing Issues and Experiences in West Bengal Market Perspective
}

\author{
Abdhesh Kumar Singh, Pramod Pathak, Saumya Singh
}

\begin{abstract}
The knowledge of Rural Marketing in Indian Economy has continuously played an important role in the existence of individuals. The rural market in India contributes larger revenues in the nation, as the rural areas contain most of the consumers in this country. Indian Rural Marketing has always been tough to do area and comprise of uniqueness. Though many enterprises were effective in influencing the rural markets, they captured the market with appropriate innovative marketing moves. As two-third of Indian population resides in rural areas, the market is massive for the businesses to be present and effective in all rural markets. They have to carry out few experiments in areas such as pricing and supply chain. The current paper intends to know the marketing issues and experiences in Indian market. The foremost aim of this study is to notice the potential of Indian rural markets and finding out several difficulties being faced by rural markets.
\end{abstract}

Keywords: Rural Marketing, Telecom services, Rural Infrastructure Report, telecommunication services.

\section{INTRODUCTION}

Digital technology has been a prominent medium now a days through which companies grow their businesses. The digital channel is used for promoting product and services and to reach consumers and is called digital marketing. The means and modes of digital marketing are e.g. mobility, social media, content marketing, search engine marketing and advanced analytics. In India, out of total population of 121 crores, 83.3 crores live in rural areas (Census of India, 2011). Thus, nearly 70 per cent of the India's population lives in rural areas. These rural populations can be characterized by mass poverty, low levels of literacy and income, high level of unemployment, and poor nutrition and health status. In order to tackle these specific problems, a number of rural development programmes are being implemented to create opportunities for improvement of the quality of life of these rural people.

The Indian rural market has been growing steadily over the past few years and is now even bigger than the urban market. More than 800 million people live in villages of India. 'Go rural' is the marketer's new slogan. Indian marketers as well as multinationals have focused on rural

Revised Manuscript Received on July 22, 2019.

Abdhesh Kumar Singh , Research Scholar, Department of Management, IIT (Indian School of Mines), Dhanbad

Dr. Prof. Pramod Pathak, Research Supervisor, Department of Humanities \& Social Sciences/Management, IIT (Indian School of Mines), Dhanbad

Dr.Prof. Saumya Singh, Research Supervisor, Department of Humanities \& Social Sciences/Management, IIT (Indian School of Mines), Dhanbad markets. Thus, looking at the opportunities, which rural markets offer to the marketers, it can be said that the future is very promising for those who can understand the dynamics of rural markets and exploit them to their best advantage.

Rural Marketing Strategy: Rural marketing strategy is based on their A's - Availability Affordability and Acceptability. The first 'A'-Availability emphasizes on the availability of the product for the customers, i.e., this gives importance on effective distribution through efficient channels of distribution. The second ' $A$ '- Affordability which focuses on product pricing, i.e, this gives importance for smaller packages/pouches easily affordable by families in the rural areas, The third ' $A$ ' - Acceptability focuses on convincing the customers to buy the product, i.e., extending suitable promotional efforts to influence the customers to buy the product. Marketers need to understand the psycho of the rural consumers and then act accordingly.

In the current scenario, enterprises in India will have two choices - either go Global or go Rural. The price of going global is very high, and it's challenging to estimate markets in other nations. It's better to target the rural market as it is emerging day by day. Rural India is developing as a huge market for a quantity of goods and services - financial services, healthcare, education and telecommunication, etc. Here are some of the explanations why corporates are more attentive in making an drive into the rural markets:

Saturated Urban Markets- There is huge struggle in urban markets, with a extensive variability of selections of products. It's quite difficult for present enterprises to continue their businesses limited to urban markets.

Untapped Market Potential - With more than 600,000 villages, there is a huge prospect and market capacity. With a rural population of more than 833.1 million, it is a massive market.

Remittances from Abroad- Many households in rural India have one of their family members abroad (mostly in Gulf countries) or in other states within India. Individuals remit their money to their families in India and Indian states, which is a surplus source of income apart from just agriculture.

Impact of Media- The evolving reach of the electronic media has produced enormous change in the life of rural consumers. Rural individuals have started spending extra on lifestyle merchandises.

\section{LITERATURE REVIEW}

It is quite pertinent now that 
Telecom and banking have a synergistic relation. Surabhi Singh in her article on rural banking (AIMA Journal of Management \& Research,

May 2016) mentions that the communications on digital marketing can enhance the ROI of marketing. Technological innovations lead to transition from traditional marketing to digital marketing. (Bhattacharya et.al. 2000). Balasubramanya S (2002) has studied on automation of banking sector which has started with banking reforms in eighties which is followed by Narsimhan Committee. In the study he has concluded that the future will rest on integration of use of internet, proper understanding, measuring of risk management as also nurturing and retaining the intellectual capital. The author advised the following strategies which requires to be focused on: The author has advised the following strategies which requires to be focused on:

- New products need to be developed to increase customer base

- Strategic alliances

- Effective software system needs to be set up

Gamie 3(2008), undertook a research to explore the challenges of reaching low-income customers in developing markets. The whole study is just one interview based in which Anderson is asking question from Gurdeep Singh Operations Director with Hutchison Essar India. Shankar (2006) This article examines the emergence of innovation and value creation for enhancing customers' experience, as a result of increasing competition in the Indian telecom industry during the late 1990s and early 2000s.

Satya prakash Pandey (2005) feel Indian rural market can be called a "sleeping giant" since it holds vast untapped potential and Rural market environment has changed along with the rural consumer who has become conscious regarding quality and price.

The present study investigates the three dimensions of popular 3I's (Integrated- Innovative Inclusive) framework applicable in rural marketing (As advocated by Krishnamacharyulu and Ramakrishnan, 2010). The first one i.e. integrated approach seeks to integrate the efforts of organization and government in the form of public-private partnership for the rural development.

Prof. C.K. Prahlad (2007) enumerates that the future lies with those companies who see the poor as their customers. He further explains that what is needed is a better approach to help the poor, an approach that involves partnering with them to innovate and achieve sustainable win-win scenarios where the poor are actively engaged and, at the same time, the companies providing products and services to them are profitable.

\section{OBJECTIVES OF THE STUDY}

- To see the current scenario of tele services in rural areas.

- To find out challenge for tele services in rural areas in India.
- To find out experiences for teleservices in rural areas in Indian Market Perspectives

\section{Samples:}

Sample Size: 107

Sample Method: Simple Random Sampling

Sample Frame: West Bengal

Survey: Questionnaire

\section{RESULT AND INTERPRETATION}

This part of research lays importance on illustrating and interpretation of outcome based on data analysis aiming to transfer raw data into significant information. Both qualitative and qualitative data analysis techniques have been used in the study and both verbal descriptions and statistical codes have also been used in the analysis. The descriptive statistics such as degree and frequencies have been computed to interpret the qualitative data while, univariate analysis based on t-statistics, correlation coefficient, multiple linear regression, and interdependent multivariate analysis technique viz., hierarchical and nonhierarchical clustering techniques have been used to explain, enlighten and forecast the quantitative data in the study. The conclusion of data analysis have been also interpreted with value to study objectives as mentioned in the study aiming to make inferences whether the outcome are dependable with individual hypotheses or theories. Beside with this, the findings also consist of the theoretical frameworks of "Rural Entrepreneurship" and "Public-Private Partnership" on the basis of most relevant literature and secondary data.

\section{Problems Related to Rural Mobile Telecom Services}

The study starts with classification of problems related with rural mobile telecom service. Together qualitative and quantitative research techniques have been used to realize first objective of the study. In qualitative research method, an unstructured, exploratory research methodology based on small sample $($ size $=16$ ) has been used to increase insights and thoughtful of difficult circumstances. An in-depth interview based on telephonic technique has been used for data collection from the target population. A direct approach has been used in study in which purposes of the research project are disclosed to the respondents. The quantitative research methods used in study seeks to quantify the data for statistical analysis. The following section represents the findings of qualitative research design by adopting 'Open Coding Approach' and illustrated in various sub-categories and main-categories of problems related to mobile telecom services with certain proportions.

\section{Result of Qualitative Data Analysis}

The findings of qualitative data analysis apparent the difficulties related to mobile telecom services in rural West Bengal. The foremost problems identified in this initial portion of study are as follows-

Deficiency of network quality and dependability

$>$ High effective cost to maintain Base Transceiver Station (BTS)

$>$ High distribution and effective costs

$>$ Shortage of after sales services 
Lack of information and communication about marketing strategy

$>$ Trouble to complete documentation procedure to obtain new customers

$>$ Lack of technical skills and knowledge among rural people

$>$ Insufficient and lack of quality manpower to promote marketing in rural area

$>$ Retention of rural distributors is very difficult

$>$ Low awareness and knowledge for mobile telecom services in Rural area

$>$ Insufficient subscriber base and low custom

$>$ Looking for value for money

2. Result of Quantitative Data Analysis Demographic Profile of Rural Customers

Table 1 discloses that $60.8 \%$ respondents are male, whereas $39.2 \%$ are female consumers. It is also discovered that maximum consumers were within age profile of 20-30 years $(26.2 \%)$, followed by $40-50$ years $(22.4 \%)$, 30-40 years $(20.6 \%)$, less than 20 years $(17.8 \%)$ and more than 50 years $(13.1 \%)$. The statistics about education level of consumers disclose that most of the respondents $(26.2 \%)$ were with high school education, followed by illiterate $(19.6 \%)$, middle school $(14 \%)$, primary school $(13.1 \%)$, graduate $(12.1 \%)$, Diploma holders $(10.3 \%)$ and PG $(4.7 \%)$. The table also shows that majority of consumers were involved in agricultural occupation (27.1\%), followed by non-agricultural (23.4\%), salaried and labour (12.1\% each). The statistics regarding monthly household income of consumers indicate that maximum of the respondents belong to the income group of 10001-15000 INR (27.1\%) followed by $2001-5000 \operatorname{INR}(26.2 \%)$ in the sample.

Table- I: Details of Customer Profile

\begin{tabular}{|c|c|c|c|c|}
\hline & \multicolumn{4}{|c|}{ Demographic Profile } \\
\hline Sr. No. & Profile & Categories & $\begin{array}{c}\text { Frequency } \\
(\text { Out of } 107 *)\end{array}$ & Percentage \\
\hline \multirow[t]{2}{*}{1.} & \multirow[t]{2}{*}{ Gender } & Male & 65 & 60.8 \\
\hline & & Female & 42 & 39.2 \\
\hline \multirow[t]{5}{*}{2.} & \multirow[t]{5}{*}{ Age (Years) } & Less than 20 & 19 & 17.8 \\
\hline & & 20-30 & 28 & 26.2 \\
\hline & & $30-40$ & 22 & 20.6 \\
\hline & & $40-50$ & 24 & 22.4 \\
\hline & & More Than 50 & 14 & 13.1 \\
\hline \multirow[t]{8}{*}{3.} & \multirow[t]{8}{*}{ Education Level } & Illiterate & 21 & 19.6 \\
\hline & & Primary School & 14 & 13.1 \\
\hline & & Middle School & 15 & 14.0 \\
\hline & & High School & 28 & 26.2 \\
\hline & & Diploma & 11 & 10.3 \\
\hline & & Graduate & 13 & 12.1 \\
\hline & & PG & 5 & 4.7 \\
\hline & & Others & & \\
\hline \multirow[t]{3}{*}{4.} & \multirow[t]{3}{*}{ Marital Status } & Married & 71 & 66.4 \\
\hline & & Unmarried & 36 & 33.6 \\
\hline & & Others (Single) & $=$ & $=$ \\
\hline \multirow[t]{6}{*}{5.} & \multirow[t]{6}{*}{ Primary Occupation } & Regular Salary & 13 & 12.1 \\
\hline & & $\begin{array}{c}\text { Self-Employment } \\
\text { in agriculture }\end{array}$ & 29 & 27.1 \\
\hline & & Labour & 13 & 12.1 \\
\hline & & $\begin{array}{c}\text { Self-Employment } \\
\text { in Non- } \\
\text { Agriculture }\end{array}$ & 25 & 23.4 \\
\hline & & Students & 19 & 17.8 \\
\hline & & House Wife & 8 & 7.5 \\
\hline
\end{tabular}


Rural Telecom Services: Marketing Issues and Experiences in West Bengal Market Prospective

\begin{tabular}{|c|c|c|c|c|} 
6. & $\begin{array}{c}\text { Monthly House Hold Income } \\
\text { (INR) }\end{array}$ & Up to 2000 & 15 & 14.0 \\
\cline { 3 - 5 } & $2001-5000$ & 28 & 26.2 \\
\cline { 3 - 5 } & $5001-10000$ & 19 & 17.8 \\
\cline { 3 - 5 } & $\mathbf{1 0 0 0 1 - 1 5 0 0 0}$ & $\mathbf{2 9}$ & $\mathbf{2 7 . 1}$ \\
\cline { 3 - 5 } & $15001-20000$ & 10 & 9.3 \\
\cline { 3 - 5 } & More than 20000 & 6 & 5.6 \\
\hline
\end{tabular}

*Total sample size

\section{Preferences for Selecting Mobile Telecom Service Provider}

The preferences for selecting a particular mobile telecom service provider have been analyzed on the basis of frequency calculation. The ranking (from 1 to 10) for each parameter has been given from all the respondents for ten different parameters. The preference for each parameter either high or low has been ascertained on the basis of rank given by all the respondents and used in finding out the common opinion of respondents towards identifying the preferences for selecting the telecom services. It has been observed that respondents have given first rank to 'strong and reliable network', followed by 'reference of family/friends' and 'communication clarity' as second and third rank respectively for selecting the telecom services. The other parameters such as 'customer care service' and 'promotional offers' are at 8th rank, whereas the 'advertisement' and 'variety of tariff plans' are at 6th and 7 th rank respectively. It is also important to note that 'value added service', 'brand reputation' and 'celebrity endorsement' are the least preferred parameters with 10th rank (Table 2).

Table 2. Ranks for Parameters for Selecting Mobile Telecom Services Preferences for Selecting Mobile Telecom Service Providers

\begin{tabular}{|c|c|c|c|c|c|c|c|c|c|c|}
\hline \multirow[b]{2}{*}{ Parameters } & \multicolumn{10}{|c|}{ Ranking } \\
\hline & 1 & 2 & 3 & 4 & 5 & 6 & 7 & 8 & 9 & 10 \\
\hline $\begin{array}{l}\text { Strong and } \\
\text { reliable network }\end{array}$ & 33 & 15 & 10 & 5 & 7 & 6 & 12 & 9 & 8 & 2 \\
\hline $\begin{array}{l}\text { Communication } \\
\text { quality }\end{array}$ & 12 & 15 & 28 & 11 & 17 & 0 & 2 & 11 & 0 & 11 \\
\hline Advertisement & 22 & 14 & 10 & 6 & 7 & 40 & 3 & 0 & 5 & 0 \\
\hline $\begin{array}{l}\text { Customer care } \\
\text { service }\end{array}$ & 9 & 15 & 10 & 5 & 7 & 6 & 12 & 33 & 8 & 2 \\
\hline $\begin{array}{l}\text { Variety of tariff } \\
\text { plans }\end{array}$ & 9 & 7 & 5 & 6 & 11 & 13 & 28 & 14 & 4 & 10 \\
\hline $\begin{array}{l}\text { Promotional } \\
\text { offers }\end{array}$ & 2 & 8 & 11 & 5 & 0 & 12 & 17 & 25 & 15 & 12 \\
\hline $\begin{array}{l}\text { Reference of } \\
\text { family/friends }\end{array}$ & 14 & 28 & 10 & 7 & 9 & 4 & 11 & 13 & 2 & 9 \\
\hline VAS & 6 & 0 & 5 & 0 & 3 & 7 & 10 & 14 & 22 & 40 \\
\hline Brand reputation & 12 & 9 & 8 & 2 & 7 & 5 & 15 & 6 & 10 & 33 \\
\hline $\begin{array}{l}\text { Celebrity } \\
\text { Endorsement }\end{array}$ & 15 & 8 & 0 & 12 & 17 & 2 & 5 & 11 & 12 & 25 \\
\hline
\end{tabular}

*Rank preference for respective quality parameter

\section{Measuring Rural Consumers' Innovativeness and Determinants for Mobile Telecom Services}

The univariate analysis based on 'one-sample T-test' has been used for measuring the rural consumers' innovativeness and determinants. The test value of 2.5 (based on null hypothesis) has been used in evaluating the alike and p-value related for test statistics of consumer innovativeness, opinion leadership, price compassion, product contribution, need for individuality and venturesomeness has been compared with at 5 per cent level of significance for taking the decision for hypothesis. The test statistics are presented below-

Table 3. Test Statistics for Consumer Innovativeness and Determinants 


\begin{tabular}{|c|c|c|c|c|c|c|}
\hline $\begin{array}{c}\text { Innovativeness and } \\
\text { Determinants }\end{array}$ & T-Value & Sig.(1-tailed) & Mean & $\begin{array}{c}\text { Mean } \\
\text { Difference }\end{array}$ & Decision & Results \\
\hline Innovativeness & 4.95 & .000 & 2.7 & .26 & Reject $\mathrm{H}_{0}$ & Significant \\
\hline Opinion leadership & 20.85 & .000 & 3.6 & .56 & Reject $\mathrm{H}_{0}$ & Significant \\
\hline Price Compassion & 33.05 & .000 & 3.7 & 1.24 & Reject $\mathrm{H}_{0}$ & Significant \\
\hline Product Contribution & 8.81 & .000 & 2.8 & .39 & Reject $\mathrm{H}_{0}$ & Significant \\
\hline Need for Individuality & 8.94 & .000 & 2.9 & .40 & Reject $\mathrm{H}_{0}$ & Significant \\
\hline Venturesomeness & 13.50 & .000 & 3.1 & .54 & Reject $\mathrm{H}_{0}$ & Significant \\
\hline
\end{tabular}

The hypothesis to measure consumer innovativeness and determinants is expressed as-

Null H01: $\mu \leq 2.5$ (The rural consumers' innovativeness, opinion leadership, price compassion, product contribution, need for individuality, and venturesomeness towards mobile telecom services are insignificant)

Alternative HA1: $\mu>2.5$ (The rural consumers' innovativeness, opinion leadership, price compassion, product contribution, need for individuality, and venturesomeness towards mobile telecom services are significant)

The Table 3 specifies that all the p-values related with 'one- sample T-test' is less than 0.05 (at 5\% level of significance), hence we reject the null hypothesis for all these paradigms and conclude that rural consumers' innovativeness, opinion leadership, price compassion, product contribution, need for individuality, and venturesomeness towards mobile telecom services are significant.

\section{Over all Model Fit}

The statistical significance of regression model is based on 'overall model fit' and tests the hypothesis that the quantity of variation described by the regression model is more than the base line forecast i.e. R2 is significantly greater than zero. Each sum of squares with its correct degrees of freedom produces an approximation of variance. The top portion of F-ratio specifies the variance explicated by the regression model and the bottom portion indicates unsolved variance. The overall model fit depends on the regression variate, whether it is important in amplification the dependent variable or not. The Fstatistics indicates the consequence of ratio to determine the variance from zero. If it is statistically significant, the scholar can make assumption that the regression model not only valid for the specific sample of study but would be predictable to be significant for the multiple model of samples from the population.

Table 4. Over all Model Fit ANOVA

\begin{tabular}{|c|c|c|c|c|c|c|}
\hline \multicolumn{2}{|c|}{ Model } & $\begin{array}{c}\text { Sum of } \\
\text { Squares }\end{array}$ & df & Mean Square & F & Sig. \\
\hline \multirow{2}{*}{} & Regression & 401.513 & 5 & 80.303 & $\mathbf{1 5 3 . 5 4}$ & $\mathbf{. 0 0 0}$ \\
\cline { 2 - 7 } & Residual & 309.122 & 591 & .523 & & \\
\cline { 2 - 8 } & Total & 710.635 & 596 & & & \\
\hline
\end{tabular}

The F- ratio 153.54 as mentioned in overall model is calculated on the basis of the following formulae-

$$
\text { Sum of Squares (regression) / Degrees of Freedom (regression) }
$$

F ratio=

Sum of Squares (residual) / Degrees of Freedom (residual)

Table 5. T-test Statistics for Determinants 
Rural Telecom Services: Marketing Issues and Experiences in West Bengal Market Prospective

\begin{tabular}{cccc} 
Predictors & $\begin{array}{c}\text { Regression } \\
\text { Coefficient (B) }\end{array}$ & Std. Error & t-test statistics (t) \\
\hline Opinion leadership & .651 & .041 & $\mathrm{t}=0.651 / 0.041=15.7^{*}$ \\
\hline Price compassion & .205 & .031 & $\mathrm{t}=0.205 / 0.031=6.62^{*}$ \\
\hline Product contribution & -.063 & .033 & $\mathrm{t}=-.0603 / 0.033=-1.93$ \\
\hline Need for individuality & .014 & .031 & $\mathrm{t}=0.014 / 0.031=0.452$ \\
\hline Venturesomeness & .346 & .036 & $\mathrm{t}=0.346 / 0.036=9.68^{*}$
\end{tabular}

\section{Significant at 5\% level of significance}

It can be seen in the Table (5) that opinion leadership ( $\mathrm{t}=$ 15.717, $\mathrm{p}<0.05$ ), price compassion ( $\mathrm{t}=6.62, \mathrm{p}<0.05)$, and venturesomeness $(\mathrm{t}=9.68, \mathrm{p}<0.05)$ significantly affect consumer innovativeness, hence we reject the null hypothesis for these factors, whereas product contribution $(\mathrm{t}=-1.93, \mathrm{p}$ $>0.05)$, and need forindividuality $(t=0.452, p>0.05)$, do not significantly affect rural consumer innovativeness for mobile telecom services.

\section{MAJOR FINDINGS}

- Age wise analysis explains the pattern of purchasing in the rural markets where in the age group between 21-30 years is dominating, with majority of males persons.

- Marketers can gain most if they can make the rural people feel that they them as their consumers.

- Regional languages are part of vital dynamics in rural marketing.

- Rural consumers are progressively becoming brand aware as well as with price and discounts.

- The decision-making in the rural market are taken by self, followed by significant others.

- The rural consumers usually do not try-out a new product unless something prompts them.

- From the study it can be concluded that there is a high potential in rural India but there is major gap between the existing and the desirable levels of rural marketing.

\section{CONCLUSION}

In recent days, every industry is getting engaged with rural areas, since the urban areas are practically saturated. And the rural areas are having possibility to progress and this is the accurate time for the marketers to enhance their market shares. The customers' relocation is more towards urban markets and this is one of the foremost disadvantages of the teleservices companies. To overawe these they have to accept some of the marketing approaches to protect the consumers and retain their present customers. They can work towards attitudinal changes in the rural consumers' innovativeness, opinion leadership, price compassion, product contribution, need for individuality, and venturesomeness to contend in this competitive yet prospective rural market.

\section{Limitations of the Study}

The present study is established on West Bengal State only and the outcomes and their suggestions grieves from limitations with esteem to the geographical scope, location of the population, socio-cultural and economic variances. Only nearby Kolkata, Bardhhaman, Howrah rural area have been selected. These may not be representative of the whole of West Bengal. While piloting the analysis, the selected respondent was the chosen adopter member among other followers of the domestic and his/ her answers may be affected by bias.

\section{Scope for Further Research}

Since the study is confined to West Bengal only, the scholars may emphasis on the other parts of the state and country to endure the research to simplify the outcomes of this study. Interested researchers may focus on marketing strategy to take added in-depth information of the rural areas. Meanwhile the popular of the adopters are not common employers of the amenities and more or less they aspect problematic in effective the tele services, so their technology and proper marketing strategy awareness is negative. But once they lay hand on the classification after a gap of phase, knowledge awareness can be encompassed in revision development for rural market.

\section{REFERENCES}

1. Aithal, R.K. and Vaswani, L.K. (2005). Distribution Channel Structure in Rural Areas: A Framework and Hypotheses Decision, 32(1): January-June 2005, 191-206.

2. Anugrah Madison (2005) Rural Marketing, Himalaya Publishing House, Mumbai, 5

3. Awdhesh Kumar Singh and Satya Prakash Pandey, Rural Marketing Indian Perspective, New Age International Publishers, 2005.

4. Bhatnagar, S. (2000). Enhancing telecom options in rural India: Some options, India Telecom Conference. Stanford.

5. Bhattacharya, A., Lin, P., Steward, R. (2000). 1(1)R-9-28 interacts with genes in the dorsal-ventral pathway in Drosophila. A. Dros. Res. Conf. 41 : 522B.

6. Huhmann, S. (2005). Tapping India's Rural Market Journal of Students Research, 93-100.

7. Field, A. (2005). Discovering statistics using SPSS (2nd ed.). London: Sage.

8. R.V. Badi, N.V. Badi, Rural Marketing, Himalaya Publishing House, 2004.

9. Singh Awadesh Kumar and Pandey Satyaprakash, 2005. Rural Marketing- Indian Perspective, New Age International Publishers, Delhi.

10. Taneja, G. and Kaushik, N. (2007). Customer Perception Towards Mobile Service Provider: An Analytical Study Indian Journal of Services Marketing September 2007 